\title{
THE EFFECTS OF UNCONTROLLED EXTRACTIONS OF THE PERMANENT LOWER FIRST MOLARS ON THE PROGNOSIS OF SPONTANEOUS SPACE CLOSURE AND OCCLUSION
}

\section{ABSTRACT}

Objectives: This cross-sectional study aimed to evaluate the prognosis of spontaneous space closure and occlusion in uncontrolled permanent lower first molar extractions in patients with different developmental stages.

Materials and Methods: Fifty permanent lower first molar extractions were included in the study. Extractions were divided into two groups as appropriatetiming (Group 1- 6th or 7th stages of Nolla) and late-timing (Group 2- 8th or 9th stages of Nolla), according to the Nolla calcification stage of permanent second molar germs in the same quadrant. In the 24th month, based on clinical/radiological/ photographic data, the success of spontaneous space closure, rotation degrees of adjacent teeth, and dental midline deviations were evaluated.

Results: Successful spontaneous space closure was observed in 52\% in Group 1 , and no successful result was present in Group 2. The difference was statistically significant $(\mathrm{p}<0.001)$. Rotation results of adjacent teeth were determined more frequently in Group 2, and the difference was not statistically significant $(\mathrm{p}=0.138, \mathrm{p}=0.084, \mathrm{p}=0.120)$. Dental midline deviations were statistically significantly higher in unilateral extractions compared to bilateral extractions $(\mathrm{p}=0.006)$.

Conclusions: The timing of permanent lower first molar extractions for successful spontaneous space closure should be planned at the sixth or seventh development stage of the permanent lower second molar, according to Nolla's classification. Since rotations in adjacent teeth occur regardless of extraction timing, cases should be followed-up and intervened if necessary. Besides, unilateral permanent first molar tooth extractions should be avoided as much as possible since they cause dental midline deviation.

Key Words: Dental occlusion, malocclusion, tooth extraction.
Melike Kiraz Canpolat ${ }^{1}$

(D) *Akif Demirel ${ }^{1}$

(D) Mustafa Aydinbelge ${ }^{2}$

(ID) Şaziye Sarı ${ }^{1}$

ORCID IDs of the authors: M.K.C. 0000-0001-9307-0195 A. D. $0000-0002-1433-0452$

M. A. $0000-0003-3610-4031$

S..S. $\quad 0000-0003-2202-5148$

How to Cite: Canpolat MK, Demirel A, Aydınbelge M, Sarı Ş. The Effects of Uncontrolled Extractions of the Permanent Lower First Molars on the Prognosis of Spontaneous Space Closure and Occlusion. Cumhuriyet Dent J 2020;23:3:181-190.

* Corresponding Author:

Department of Pediatric Dentistry, Ankara University, Faculty of Dentistry, Ankara, 06560, Turkey

$\begin{array}{lll}\text { Tel: }+903122965670 & \text { Fax: }+903122123954 & \text { E-mail: akifdemirel@ankara.edu.tr }\end{array}$ 


\section{INTRODUCTION}

Maintenance of permanent first molar teeth in the mouth functionally is essential because of their critical role in the development of occlusion and mastication. ${ }^{1}$ However, dental caries is one of the most common diseases around the world ${ }^{2}$, and since the permanent first molars are the most affected by caries and hypomineralization, extraction may be necessary due to excessive loss of crown structure and extensive periradicular infections during different dentition periods. ${ }^{3}$

As a result of the extraction of permanent first molar teeth in proper time, it is stated that permanent second molars will take a proper position by mesialization to the extraction space. The appropriate extraction time for obtaining an acceptable and ideal dental occlusion is the period between the completion of crown formation and the development of one-third of the root structure of permanent second molars. ${ }^{4-7}$ This stage coincides with the period between " 6 or 7" according to the Nolla classification and "E" according to the Demirjian classification. ${ }^{8-11}$ In the classifications of Demirjian and Nolla, the developmental stages of the teeth can be determined based on the level of calcification..$^{8,9,12}$ Also, it is recommended that the mineralization in furcation of the second permanent molars should be detected radiographically.,

The spongious structure of the upper jaw and the distal eruption direction of the permanent second molars increase the possibility of parallel movement of these teeth. Therefore, the early and late extractions in the upper jaw usually result in successful spontaneous space closure. However, if extractions are performed in the early period, there may be a residual space $(5-10 \mathrm{~mm}$.) between the permanent second molars and the second premolars. It is also reported that in case of late extraction, tipping of the permanent second molars and mesiopalatal rotation around the palatal root may be observed. ${ }^{13}$

Due to the compact structure of the lower jaw that allows more complex tooth movements and the mesial eruption direction of the permanent second molars, the tipping of these teeth may be seen during the mesial movement. Therefore, early and late extractions cause more complicated results in the lower jaw., ${ }^{5,14}$ In early extractions, if the primary second molar is also lost early, the second premolars show distal movement, distal tipping, or rotational movements in the eruption phase. ${ }^{10}$ In late extractions in the lower jaw, crossbite, occlusal disharmony in the non-working side, and distal tipping of the second premolar may be observed as a result of mesiolingual tipping of the permanent second molar tooth. Besides, it is reported that inappropriate contact relationships can cause periodontal diseases and atrophy of the alveolar bone. ${ }^{13}$

Although the possible results of uncontrolled extractions of the permanent first molars have been described, there are no evidence-based clinical studies in the literature. This cross-sectional study aims to evaluate the prognosis of extraction space, spontaneous space closure, rotation of the adjacent teeth, and dental midline deviations in unilateral/bilateral extractions of lower permanent first molars in two different developmental stages.

\section{MATERIALS AND METHODS Ethical Approval}

The study protocol was approved by the Ethics Committee of Erciyes University, Faculty of Medicine (approval ID: 2020/39-decision date: 15/01/2020). All procedures of the presented research were completed based on the Declaration of Helsinki. Also, the written informed consent forms were signed by the parents and patients.

\section{Study Design}

The present cross-sectional research was conducted on patients who had presented to the Pediatric Dentistry Clinics of Erciyes University or Ankara University between 2012 and 2016 with the indication of unilateral or bilateral permanent lower first molar extraction. The main extraction indications were as follows: i) non-restorable extensive dental caries, ii) developmental dental anomalies/defects (hypomineralization, defects of enamel or dentin), iii) excessive periradicular/ perifurcal lesions. In this study, preoperative intraoral photographs and panoramic radiographs, together with postoperative (on $24 \pm 2$ nd month) clinical examination findings and intraoral photographs, were used for assessment of 
spontaneous space closure, rotation degree of adjacent teeth, and midline deviations.

\section{Inclusion Criteria}

Considering the medical and dental history, photographic records, and panoramic radiographic examinations; inclusion criteria were as follows:

- Patients without dental anomalies

- Cases with at least one lower permanent first molar tooth extraction

- Patients with preoperative and postoperative (on 24 \pm 2nd month) panoramic radiographs and intraoral photographs

- Angle Class I cases (diagnosed with panoramic radiographs and intraoral photographs)

- Patients without skeletal or dental bite anomalies

- Patients without severe anterior crowding

According to the inclusion criteria, 50 teeth (in 39 patients) were found to be appropriate for research design and included in the study.

\section{Inter-Examiner Reliability}

Determination of the study groups and evaluation of the results were performed by two different examiners. The agreement between the examiners was determined by using Cohen's Kappa Test, and values 0.8 or above demonstrated good reliability. In this study, the mean $\mathrm{k}$ value was 0.90 .

\section{Determination of the Study Groups}

The cases included in the present study were divided into two groups by using radiographic data according to Nolla's development stage of the permanent lower second molar germs on the side of extraction. Group 1 referred to the ideal period (appropriate timing) for the extraction of permanent first molars, whereas Group 2 referred to the late period.

\section{Group 1}

Group 1 included 25 teeth (in ten female and ten male patients) at Nolla stages ${ }^{8} 6$ (7 teeth) or 7 (18 teeth). The average age was determined as 8.6 (7 to 11 ) years.

\section{Group 2}

Group 2 included 25 teeth ( 8 females and 11 males) at Nolla stages 8 (12 teeth) or 9 (13 teeth). The average age was determined as 11.7 (11 to 13 ) years.

\section{Evaluation Criteria}

\section{Evaluation of Spontaneous Space Closure}

The success of spontaneous space closure was evaluated by clinical radiographical examination for Groups 1 and 2 included in the study at 24th-month control. In clinical examination, the residual extraction space was recorded by measuring the distance between the distal surface of the anterior tooth and the mesial surface of the posterior tooth using a digital caliper. It was considered as "successful" when appropriate contact relations were obtained between the permanent second molars and the second premolars, together with the absence of severe rotation results in adjacent teeth. The "unsuccessful" conditions regarding space closure were as follows:

\section{Condition 1:}

A: Inappropriate space closure due to overeruption of the upper permanent first molar and consequent tipping of the lower second premolar (5 to $10 \mathrm{~mm}$. of space between the permanent second molar and the second premolar).

B: Inappropriate space closure due to tipping of the permanent second molar or the second premolar (5 to $10 \mathrm{~mm}$. of space between the permanent second molar and the second premolar).

\section{Condition 2:}

A: Inappropriate space closure due to overeruption of the upper permanent first molar and consequent tipping of the lower second premolar $(<5 \mathrm{~mm}$. of space between the permanent second molar and the second premolar).

B: Inappropriate space closure due to tipping of the permanent second molar or the second premolar ( $<5 \mathrm{~mm}$. of space between the permanent second molar and the second premolar).

\section{Condition 3:}

Condition 3 includes the appropriate contact relation between the permanent second molar and the second premolar as a result of the distalization of the second premolar. However, this condition showed that inappropriate space closure with 
residual extraction space occurred between the first and second premolars.

It was evaluated whether there was a statistically significant difference between Group 1 and Group 2 regarding space closure success.

\section{Evaluation of Rotations}

Rotations in permanent second molar and second premolar teeth were evaluated by clinical examination and intraoral photographs based on the tooth position on the alveolar crest for each study group (Groups 1 and 2). On intraoral photographs, the angle between the line passing through the buccolingual direction of the tooth and the alveolar crest direction was considered as the rotation angle. Rotation angles $<45^{\circ}$ were defined as mild, and those $>45^{\circ}$ were defined as severe. It was evaluated whether there was a statistically significant difference between Group 1 and Group 2 regarding rotation results.

\section{Evaluation of Dental Midline Deviations}

In the evaluation of dental midline deviation, all cases in this study were divided into two groups according to the extractions being unilateral $(n=34)$ or bilateral $(n=8)$ regardless of developmental stages of the permanent second molars. Dental midline deviations due to the distalization of canines and incisors were determined by clinical examination findings. It was evaluated whether there was a statistically significant difference between unilateral and bilateral extraction groups for dental midline deviation.

\section{Statistical Analysis}

Statistical analysis of the results was performed by using SPSS 11.5 Software-Windows version. Number (percentage) was used for descriptive qualitative variables. When the relation between two qualitative variables was analyzed, Chi-Square and Fisher-Exact tests were used. The statistical significance level was determined as $5 \%$.

\section{RESULTS}

\section{Results of Spontaneous Space Closure:}

The success rates of spontaneous space closure in Group 1 (Nolla Stage 6 or 7) was 52\% (Table 1, Figure 1).

Table 1. The results of spontaneous space closure for each group and the statistical comparison between Group 1 and 2

\begin{tabular}{|c|c|c|c|c|c|c|c|}
\hline \multirow{3}{*}{\multicolumn{3}{|c|}{ Variables }} & \multicolumn{4}{|c|}{ Groups } & \multirow{3}{*}{$\mathrm{p}$-value } \\
\hline & & & \multicolumn{2}{|c|}{ Group 1} & \multicolumn{2}{|c|}{ Group 2} & \\
\hline & & & $\mathrm{n}$ & $\%$ & $\mathrm{n}$ & $\%$ & \\
\hline \multirow{4}{*}{ Space Closure } & \multicolumn{2}{|c|}{ Successful } & 13 & 52.0 & 0 & 0.0 & \multirow{4}{*}{$<0.001 *$} \\
\hline & \multirow{3}{*}{ Unsuccessful } & $\begin{array}{l}\text { Condition } 1 \\
\qquad(1 \mathrm{~A}+1 \mathrm{~B})\end{array}$ & 6 & 24.0 & 11 & 44.0 & \\
\hline & & $\begin{array}{c}\text { Condition } 2 \\
(2 \mathrm{~A}+2 \mathrm{~B})\end{array}$ & 4 & 16.0 & 14 & 56.0 & \\
\hline & & Condition 3 & 2 & 8.0 & 0 & 0.0 & \\
\hline
\end{tabular}

(* indicates statistical significance, Fisher-Exact test)

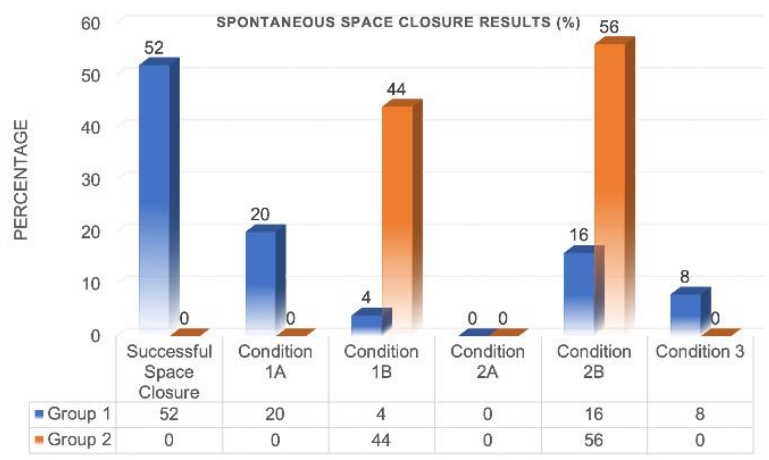

Figure 1: The distribution (percentage-\%) of the results of space closure.
In the evaluation for spontaneous space closure of the cases in Group 1:

- Space closure was considered as successful in 13 teeth $(52 \%)$ (Figure 2$)$.

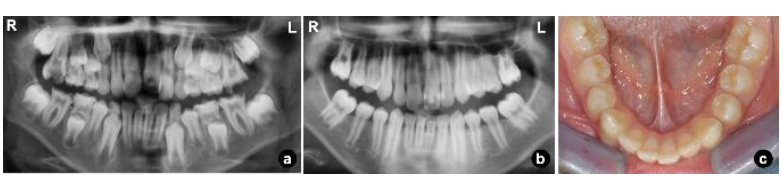

Figure 2: Panoramic radiographic image of the right and left lower permanent first molars which required extraction in a case in Group 1 (a). Radiographic (b) and intraoral (c) images at the 24-month followup of a case that was considered successful because of the mesialization of the permanent lower second molar to the extraction space and appropriate contact relations (b).

- Inappropriate space closure was observed due to the overeruption of upper permanent first molar in five teeth (20\%) (Condition 1A) (Figure 3). 

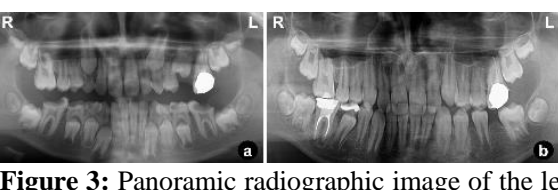

Figure 3: Panoramic radiographic image of the left permanent lower first molar tooth that required extraction in a case in Group 1 (a). Radiographic (b) and intraoral (c) images at the 24-month follow-up of a case with inappropriate space closure that was considered unsuccessful due to overeruption of the upper permanent first molar (Condition 1A).

- $8 \mathrm{~mm}$. of residual space between the permanent lower second molar and second premolar was observed in one tooth (4\%) due to the tipping of the lower permanent second molar (Condition 1B).

- $<5 \mathrm{~mm}$. of residual space between the permanent lower second molar and second premolar was observed in four teeth (16\%) due to tipping of the lower permanent second molar (Condition 2B).

- Inappropriate space closure was observed in two teeth $(8 \%)$ due to the distalization of the second premolar (Condition 3) (Figure 4).

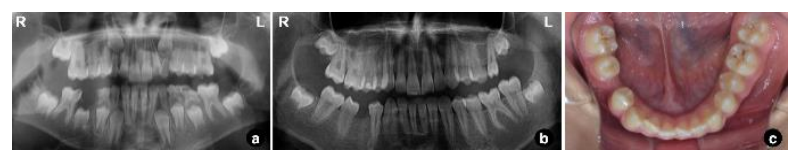

Figure 4: Panoramic radiographic image of the right permanent lower first molar tooth, which required extraction in a case in Group 1 (a). Radiographic (b) and intraoral (c) images at the 24-month follow-up of a case with inappropriate space closure that was considered unsuccessful due to the distalization of the lower second premolar (Condition 3).
All of the cases in Group 2 (Nolla Stage 8 or 9) (n = 25) were found to be unsuccessful regarding space closure (Table 1, Figure 1).

In the evaluation for space closure of the cases in Group 2:

- 5-10 mm. of residual space between the permanent lower second molar and second premolar was observed in 11 teeth $(44 \%)$ due to tipping of the permanent lower second molar (Condition 1B) (Figure 5).

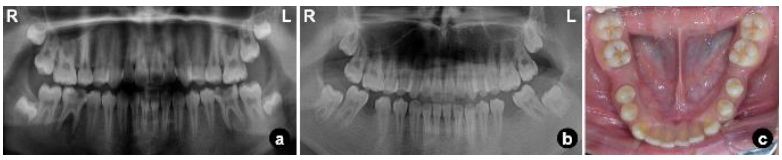

Figure 5: Panoramic radiographic image of the right and left permanent lower first molar teeth, which required extraction in a case in Group 2 (a). Radiographic (b) and intraoral (c) images at the 24month follow-up of a case that was considered unsuccessful with residual spaces between the permanent lower second molar and second premolar [Right $<5 \mathrm{~mm}$. (Condition 2B), left: 5-10 mm. (Condition 1B)] due to the tipping of the lower second premolar.

- $<5 \mathrm{~mm}$. of residual space between the permanent lower second molar and second premolar was observed in 14 teeth $(56 \%)$ due to tipping of the lower permanent second molar (Condition 2B) (Figure 5).

Statistical analysis of two groups regarding success in achieving space closure revealed that differences between the groups were statistically significant $(\mathrm{p}<0.001)$ (Table 1).

\section{Results of Rotation of Adjacent Teeth:}

In the evaluation for rotation of the adjacent teeth in Group 1 (Table 2, Figure 6):

Table 2. Results of rotation of the adjacent teeth in each group and the statistical comparison between Group 1 and 2 (a: Chi-Square test, b: Fisher-Exact test)

\begin{tabular}{|c|c|c|c|c|c|c|}
\hline & & \multicolumn{4}{|c|}{ Groups } & \multirow{3}{*}{ p-value } \\
\hline \multicolumn{2}{|c|}{ Variables } & \multicolumn{2}{|c|}{ Group 1} & \multicolumn{2}{|c|}{ Group 2} & \\
\hline & & n & $\%$ & n & $\%$ & \\
\hline \multirow{3}{*}{$\begin{array}{l}\text { Rotation results of } \\
\text { permanent second } \\
\text { molars }\end{array}$} & Absent & 7 & 28.0 & 2 & 8.0 & \multirow{3}{*}{$0.138^{b}$} \\
\hline & Mild & 18 & 72.0 & 23 & 92.0 & \\
\hline & Severe & 0 & 0.0 & 0 & 0.0 & \\
\hline \multirow{3}{*}{$\begin{array}{l}\text { Rotation results of } \\
\text { second premolars }\end{array}$} & Absent & 12 & 48.0 & 7 & 28.0 & \multirow{3}{*}{$0.084^{\mathrm{a}}$} \\
\hline & Mild & 11 & 44.0 & 10 & 40.0 & \\
\hline & Severe & 2 & 8.0 & 8 & 32.0 & \\
\hline \multirow{3}{*}{$\begin{array}{l}\text { Rotation results of } \\
\text { first premolars }\end{array}$} & Absent & 16 & 64.0 & 9 & 36.0 & \multirow{3}{*}{$0.120^{\mathrm{b}}$} \\
\hline & Mild & 8 & 32.0 & 14 & 56.0 & \\
\hline & Severe & 1 & 4.0 & 2 & 8.0 & \\
\hline
\end{tabular}




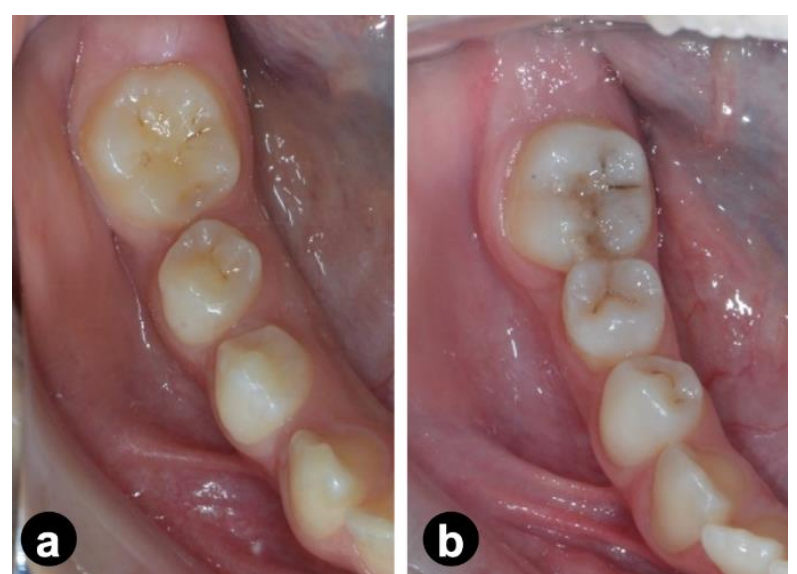

Figure 6: Intraoral images of mild rotation (Group 1) (a) of the permanent second molar and severe rotation (Group 2) (b) of the second premolar.

- There was no rotation in seven permanent lower second molars $(28 \%)$, whereas mild rotation was observed in 18 teeth $(72 \%)$.

- There was no rotation in 12 lower second premolars (48\%). A mild rotation was observed in 11 lower second premolars (44\%), whereas severe rotations were observed in two of the second premolars $(8 \%)$.

- There was no rotation in 16 lower first premolars (64\%). A mild rotation was observed in eight lower first premolars $(32 \%)$, and a severe rotation was observed in one first premolar (4\%).
In the evaluation for rotation of the adjacent teeth in Group 2 (Table 2, Figure 6):

- There was no rotation in two lower permanent second molars $(8 \%)$, whereas a mild rotation was observed in 23 teeth (92\%).

- There was no rotation in seven lower second premolars (28\%). A mild rotation was observed in ten lower second premolars (40\%), whereas eight of the second premolars had severe rotations $(32 \%)$.

- There was no rotation in nine lower first premolars (36\%). A mild rotation was observed in 14 lower first premolars (56\%), whereas two of the first premolars had severe rotations $(8 \%)$.

In statistical analysis, there was no statistically significant difference between the groups regarding the rotation of the adjacent teeth (Table 2).

\section{Results of Dental Midline Deviation:}

In the evaluation for midline deviation, midline deviation was observed in 27 cases in unilateral extractions $(79.4 \%)$ and two cases in bilateral extractions (25\%). The difference between unilateral and bilateral extractions was found to be statistically significant $(\mathrm{p}=0.006)$ (Table 3, Figure 7).

Table 3. Midline deviation results and the statistical comparison between unilateral and bilateral extractions (* indicates statistical significance, Fisher-Exact test)

\begin{tabular}{|c|c|c|c|c|c|}
\hline \multirow{3}{*}{ Variables } & \multicolumn{5}{|c|}{ Dental Midline Deviation } \\
\hline & \multicolumn{2}{|c|}{ Presence } & \multicolumn{2}{|c|}{ Absence } & \multirow{2}{*}{ p-value } \\
\hline & $\mathbf{n}$ & $\%$ & $\mathbf{n}$ & $\%$ & \\
\hline Unilateral Extractions & 27 & 79.4 & 7 & 20.6 & \multirow{2}{*}{$0.006 *$} \\
\hline Bilateral Extractions & 2 & 25.0 & 6 & 75.0 & \\
\hline
\end{tabular}

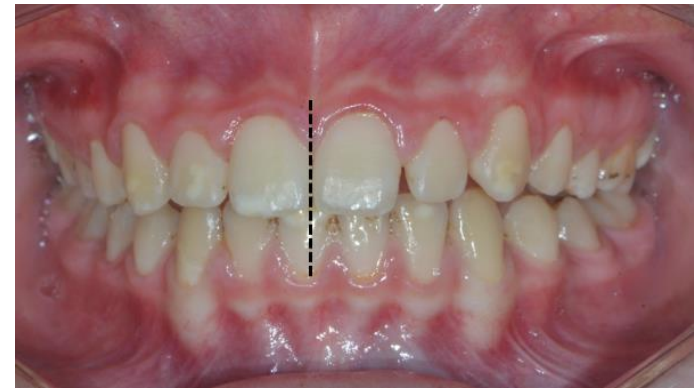

Figure 7: Intraoral image of dental midline deviation in a case with unilateral extraction.

\section{DISCUSSION}

Studies evaluating the prognosis of spontaneous space closure of the permanent first molars have reported that extractions in the upper jaw mostly achieved an acceptable occlusion. ${ }^{6,10,11,15-17}$ However, in the lower jaw, due to the biological structure of bone tissue and the eruption direction of the permanent second molars, the results of early and late permanent first molar extractions may become more complicated. ${ }^{5,14}$ Therefore, the present study aimed to investigate the effect of lower first molar tooth extractions on the prognosis of occlusion in two different dental developmental stages. 
The molar occlusion relation should be Angle Class I in order to obtain an acceptable and ideal occlusion while deciding on the extraction of the permanent first molar teeth. Lower first molar tooth extractions should be avoided as much as possible in Angle Class II, Division II cases, whereas upper first molar tooth extractions in Angle Class III. However, if a tooth extraction is required due to dental necessities, it should be consulted with Orthodontics not to exacerbate the malocclusion. ${ }^{18-}$

${ }^{21}$ In a study by Teo et al. ${ }^{10}$, even though the study included patients in Angle Class I, II, and III in contrast to the present study, the authors reported that space closure success rates were higher in Angle Class I patients compared to the other groups. For this reason, cases with Angle Class I molar relationship were included in the present study.

It has been stated that the appropriate extraction time was the calcification period of bifurcation area of the permanent second molars to achieve successful spontaneous space closure after extraction of the permanent first molar teeth..$^{5,7,8}$ This timing is equal to the sixth and seventh stages of Nolla classification. As a result of performing extractions later than these stages, tipping, displacement, overeruption, and occlusal abnormalities develop in the adjacent teeth. For this reason, in our study, two study groups were included as appropriate (Nolla stage 6 or 7) and late (Nolla stages 8 or 9) extractions.

The patients were evaluated regarding space closure at the 24-month follow-up examination. Space closure was found to be successful in 13 cases $(52 \%)$ in Group 1, which included the cases with the permanent second molars at the 6th or 7th stage according to the Nolla classification. However, there was no successful result in Group 2 , which included the permanent second molars at the eighth or ninth stages of Nolla classification, and this difference was statistically significant $(p<0.001)$. In related studies, success rates similar to our study were reported for space closure. Teo $e t$ al. ${ }^{10}$ reported the success of space closure as $66 \%$ in lower first molar extraction at the ideal developmental stage (Demirjian's stage E) of the permanent second molar.
Similarly, Patel et al. ${ }^{11}$ stated that $49 \%$ of 153 permanent first molar extractions in the lower arch had successful space closure. However, Teo et al. ${ }^{10}$ and Patel et al. ${ }^{11}$ concluded that the dental age or the developmental stage of the permanent second molars had no significant effect on the success of space closure in the lower dental arch. The authors stated that successful space closure was achieved in the early and late developmental periods. In this regard, we thought that the authors' reporting of successful space closure in the out-of-ideal developmental stage might have been related to using Demirjian's classification. However, Jälevik and Möller ${ }^{16}$ reported the success rate of space closure as $66 \%$ after the upper and lower permanent first molar extractions. The authors emphasized that optimal spontaneous space closure could be observed when first molars were extracted prior to the eruption of the second molar teeth. ${ }^{16}$

Condition 1A, which indicates unsuccessful space closure due to overeruption of the upper permanent first molar tooth, was observed in five cases (20\%) in Group 1 and not in Group 2. Therefore, it is possible to say that overeruption is more likely to occur in the early mixed-dentition period., "Compensation Extractions," which expresses controlled extraction of the upper permanent first molars, was recommended to avoid such a failure caused by overeruption of the upper first molar tooth. However, to perform these extractions, various requirements should be provided. The cases should be in the period of mixed-dentition, not include congenital tooth agenesis, involve an Angle Class I molar relationship, and also, overjet and overbite should be within normal limits. ${ }^{3,13}$ There is no evidencebased clinical study evaluating compensation extractions of the permanent first molars. However, in a study ${ }^{15}$ evaluating the necessity of controlled extractions, the authors stated that compensation extractions were required in $17 \%$ of cases.

Condition 1B, which indicates unsuccess in space closure (5-10 $\mathrm{mm}$. of residual space) due to tipping of the lower permanent second molar tooth to the extraction space, was observed in one case in Group 1 (4\%) and 11 cases in Group 2 (44\%). 
Condition 2B, which indicates unsuccess in space closure ( $<5 \mathrm{~mm}$. of residual space) due to tipping of the adjacent teeth to the extraction space, was observed in 4 cases (16\%) in Group 1 and 14 cases (56\%) in Group 2. It is also known that late extractions increase the probability of failure and may cause complications such as tipping of the adjacent teeth, inappropriate space closure, masticatory problems, periodontal diseases, and temporomandibular diseases (TMD).,10,13 As a result of the present study, while occlusal problems occurred in the cases belonging to Group 2, periodontal diseases and TMD, which require a more extended process duration to occur, were not encountered. However, it may be possible to observe these pathologies if the extraction cases are followed-up for more extended periods. Therefore, it is suggested that it will be more suitable to make a further evaluation. Concerning Condition 3, which indicates space closure by distalization of the second premolar, was observed in two cases (8\%) in Group 1; however, it was not detected in Group 2. Jälevik and Möller ${ }^{16}$ stated that distalization occurred in the second premolar tooth in three cases (\%10), and the germs of all these teeth were inclined distally in the alveolar bone, similar to our study. In cases with an eruption in the distal direction of the second premolar teeth, it is possible to say that it would be beneficial to monitor at regular intervals and perform necessary treatment procedures.

In our study, the cases were evaluated in terms of rotations of adjacent teeth at the 24-month examination, and mild rotation was observed in 18 (72\%) permanent second molar teeth in Group 1 and 23 (92\%) teeth in Group 2. A statistically significant difference was not present between the two groups $(\mathrm{p}=0.138)$. Similarly, rotation results were detected in the first and second premolars, and no statistically significant difference was present between Groups 1 and $2(\mathrm{p}=0.120$ for the first premolars, $\mathrm{p}=0.084$ for the second premolars). Teo et al. ${ }^{10}$ reported that rotations could be observed in permanent second molars or second premolars, even when permanent first molars had been extracted at the ideal root developmental stage of the permanent second molars in the lower jaw. Additionally, since the rotation occurring in adjacent teeth is independent of the timing of extraction, all extraction cases should be monitored at regular intervals, and all precautions should be taken. Also, the required interventions should be performed in an early period if the rotation result occurs.

In terms of midline deviation, the extraction cases were divided into two groups according to the extractions being unilateral or bilateral, and the difference was analyzed statistically. The midline deviation was detected in 27 cases $(79.4 \%)$ in unilateral extractions and two cases (25\%) in bilateral extraction cases; this difference was statistically significant $(\mathrm{p}=0.006)$. Unilateral extractions of permanent first molar teeth in the same dental arch during the growth and development period cause skeletal asymmetries in the lower facial third, together with a dental midline deviation in the long term. ${ }^{22}$ Çağlaroğlu et $a .^{22}$ reported that unilateral extractions of permanent first molars in the lower and upper jaw caused dental midline deviation; however, this was more prominent in the lower jaw. The authors also concluded that the dental midline significantly shifted towards the side of extraction in the lower and upper jaws. ${ }^{22}$ In order to avoid complications caused by unilateral extractions, "Balance Extractions" is recommended, which involves controlled extraction of the contralateral permanent first molar tooth. However, this approach has requirements similar to compensation extractions. ${ }^{3,13}$ The cases should not have congenital tooth agenesis, be in the mixeddentition period, present an Angle Class I molar relationship, and overjet/overbite should be within normal limits.

Additionally, mild crowding in the anterior or buccal segment may be acceptable. However, there is a lack of information about the amount of this crowding. ${ }^{3,13}$ Albadri et al. ${ }^{15}$ stated that compensation extractions were required in $17 \%$ of cases in their study. The cases that do not fulfill these requirements should be followed up at regular intervals and consulted with the orthodontic department if necessary. 


\section{CONCLUSIONS}

It is recommended for successful space closure that the permanent lower first molar extractions should be performed during the sixth or seventh developmental stage of permanent second molars in Nolla's classification. Rotations observed in adjacent teeth, especially in permanent lower second molars, develop regardless of the extraction timing, and therefore, patients should be followedup at regular intervals and intervened in the early period if necessary. Further evidence-based and prospective clinical trials are needed regarding controlled extractions of permanent lower first molars.

\section{ACKNOWLEDGMENT}

This research was presented as an oral presentation None.

\section{CONFLICTS OF INTEREST STATEMENT}

None.

\section{Daimi Alt Birinci Azı Dişlerinin Kontrolsüz \\ Çekimlerinin Spontan Boşluk Kapanması ve Oklüzyon Prognozuna Etkileri}

\section{$\ddot{O} Z$}

Amaç: Bu kesitsel çalışmanın amacı, farklı gelişim evrelerinde olan hastalarda, daimi alt birinci azı dişlerinin kontrolsüz çekimlerinde spontan boşluk kapanması ve oklüzyonunun prognozunu değerlendirmektir. Gereç ve Yöntemler: 50 daimi alt birinci azı diş çekimi çalışmaya dahil edilmiştir. Çekimler, aynı kadrandaki daimi ikinci azı diş jermlerinin Nolla kalsifikasyon aşamasına göre, uygun zamanlama (Grup 1- Nolla 6. veya 7. aşama) ve geç zamanlama (Grup 2- Nolla 8. veya 9. aşama) olarak iki gruba ayrılmıştır. 24. ayda klinik/radyolojik/fotoğrafik verilere dayanarak, spontan boşluk kapanmasının başarısı, komşu dişlerin rotasyon dereceleri ve dişsel orta hat sapmaları değerlendirilmiştir. Bulgular: Grup 1'de \%52 oranında başarılı spontan boşluk kapanması tespit edilirken, Grup 2'de başarll sonuç bulgulanmamıştır. Fark istatistiksel olarak anlaml düzeydedir $(p<0,001)$. Komşu dişlerin rotasyonları Grup 2'de daha çok görülmüş ve aradaki fark istatistiksel olarak anlamlı bulunmamıştır ( $p=0,138$, $p=0,084, p=0,120)$. Dişsel orta hat sapmalart, tek taraflı çekimlerde çift taraflı çekimlerden istatistiksel olarak anlamlı derecede yüksek bulunmuştur $(p=0,006)$. Sonuçlar: Başarılı spontan boşluk kapanması için, daimi alt birinci azı diş çekimlerinin zamanlaması, daimi alt ikinci azı dişlerin Nolla sınıflamasına göre 6. veya 7. gelişim aşamasında planlanmalıdır. Komşu dişlerdeki rotasyonlar çekim zamanlamasına bakılmaksızın gelişebildiği için, vakalar izlenmeli ve gerekirse müdahale edilmelidir. Ek olarak, disssel orta hat sapmasına neden olduğu için, tek taraflı daimi alt birinci azı diş çekiminden olabildiğince kaçınılmalıdır. Anahtar Kelimeler: Diş Çekimi, Diş Oklüzyonu, Maloklüzyon.

\section{REFERENCES}

1. Rajashekhara BS, Keyur JM, Bhavna D, Poonacha KS. Management of early loss of first permanent molar: A new technique. J Indian Soc Pedod Prev Dent 2012;30:349-351.

2. Celik EU, Celik B, Tunac AT. Dental Caries and Caries Associated Factors of Six and Seven Year-Old Children Living in a High Fluoride Area. Cumhuriyet Dent J 2016;19:135-144.

3. Cobourne MT, Williams A, Harrison M. National clinical guidelines for the extraction of first permanent molars in children. Br Dent J 2014;217:643-648.

4. Thilander B, Skagius S. Orthodontic sequelae of extraction of permanent first molars. A longitudinal study. Rep Congr Eur Orthod Soc 1970;429-442.

5. Mackie IC, Blinkhorn AS, Davies PHJ. The extraction of permanent first molars during the mixed dentition period - a guide to treatment planning. J Paediatr Dent 1989;5:85-92.

6. Telli AE, Aytan S. Changes in the dental arch due to obligatory early extraction of first permanent molars. Turk Ortodonti Derg 1989;2:138-143.

7. Nelson SJ, Ash MM. Development and Eruption of the Teeth, In: Wheeler's Dental Anatomy, Physiology, and Occlusion, 9th edn. St.Louis, Missouri: Saunders Elsevier, 2010.

8. Nolla CM. The development of permanent teeth. J Dent Child 1960;27:254-266.

9. Demirjian A. Tooth eruption in the French Canadian child. J Dent Que 1973;10:9.

10. Teo TK, Ashley PF, Parekh S, Noar J. The evaluation of spontaneous space closure after the extraction of first permanent molars. Eur Arch Paediatr Dent 2013;14:207-212.

11. Patel S, Ashley P, Noar J. Radiographic prognostic factors determining spontaneous space closure after loss 
of the permanent first molar. Am J Orthod Dentofacial Orthop 2017;151:718-726.

12. Karataş OH, Öztürk F, Dedeoğlu N, Çolak C, Altun O. Dental age assessment: The applicability of Demirjian method in southwestern of eastern Anatolia region Turkish children. Cumhuriyet Dent J 2012;15:130-137.

13. Gill DS, Lee RT, Tredwin CJ. Treatment planning for the loss of first permanent molars. Dent Update 2001;28:304-308.

14. Innes N, Borrie F, Bearn D, Evans D, Rauchhaus P, McSwiggan S, Page LF, Hogarth F. Should I eXtract Every Six dental trial (SIXES): study protocol for a randomized controlled trial. Trials 2013;14:59.

15. Albadri S, Zaitoun H, McDonnell ST, Davidson LE. Extraction of first permanent molar teeth: results from three dental hospitals. Br Dent J 2007;203:E14; discussion 408-409.
16. Jälevik B, Möller M. Evaluation of spontaneous space closure and development of permanent dentition after extraction of hypomineralized permanent first molars. Int J Paediatr Dent 2007;17:328-335.

17. Teo TK, Ashley PF, Derrick D. Lower first permanent molars: developing better predictors of spontaneous space closure. Eur J Orthod 2016;38:90-95. 18. Sandler PJ, Atkinson R, Murray AM. For four sixes. Am J Orthod Dentofacial Orthop 2000;117:418-434.

19. Seddon JL. Extraction of four first molars: a case for a general practitioner? J Orthod 2004;31:80-85.

20. Travess H, Roberts-Harry D, Sandy J. Orthodontics. Part 8: Extractions in orthodontics. $\mathrm{Br}$ Dent $\mathrm{J}$ 2004; 196:195-203.

21. Ong DC, Bleakley JE. Compromised first permanent molars: an orthodontic perspective. Aust Dent J 2010;55:2-14.

22. Cağlaroğlu M, Kilic N, Erdem A. Effects of early unilateral first molar extraction on skeletal asymmetry. Am J Orthod Dentofacial Orthop 2008;134:270-275. 